\title{
Effects of Securitization on Credit Risk and Banking Stability: Empirical Evidence from American Commercial Banks
}

\author{
Nesrine BEN SALAH (Corresponding author) \\ Faculty of Economic Sciences and Management of Sfax, Tunisia \\ E-mail: bsalahns@hotmail.com
}

Hassouna FEDHILA

University of Mannouba, Tunisia

E-mail: Hass530@yahoo.fr

\author{
Received: January 23, 2012 \\ Accepted: March 14, 2012 \\ Published: May 1, 2012 \\ doi:10.5539/ijef.v4n5p194 \\ URL: http://dx.doi.org/10.5539/ijef.v4n5p194
}

\begin{abstract}
This study investigates the impact of securitization on risk behavior and banking stability. Based on a sample of 174 US commercial banks from 2001 to 2008 , we find that a greater recourse to securitization is associated with a deterioration in the quality of American banks' loan portfolios and an increase of the credit risk in their balance sheets. In the other hand, we observe a positive and significant impact of securitization on banking stability. We think that this paradox is due to the fact that different classes of securitized assets lead to heterogeneous effects on American banks' stabilities. Particularly, our results show that mortgage securitization has a positive and significant impact on banking stability, providing thus a support to the implicit recourse hypothesis. Inversely, non mortgage securitization has a negative effect on banking stability because of the reduction of banks' monitoring incentives related to this particular form of securitization.
\end{abstract}

Keywords: Credit risk transfer, Securitization, Risk taking, Banking stability

\section{Introduction}

Credit risk transfer markets and particularly securitization markets have experienced a remarkable growth in recent years. According to the data from the Securities Industry and Financial Market Association (SIFMA), the global amount of securitization outstanding has increased from 5731.625 millions of dollars in the year 2001 to 13997.294 millions of dollars in the year 2008. This growth can be attributed to the diversification benefits related to securitization transactions. Intuitively, we can think that banks, by transferring their credit risk through securitization, reduce the volume of credit risk in their balance sheets.

This reasoning refers however, to a static view of risk and ignores that banks may be encouraged to increase their risk taking as a result of the increased possibilities of liquidity and risk sharing through securitization. This leads thus, to the following paradox: The credit risk can increase after a securitization transaction. To explain this idea, Gorton and Pennacchi (1995) mention the reduction of banks' monitoring incentives once their loans have been sold Santomero and Trester (1998) emphasize the effects of the liquidity improvements that loan sales techniques provide on bank's risk taking decisions. Besides, Instejford (2005) and Wagner (2007) establish that techniques of credit risk transfer reduce the amount of risk in banks' balance sheets giving the new possibilities of diversification and risk transfer out of the banking sector. This risk reduction can however, encourage an excessive risk taking from banks by reducing their efforts of selection and monitoring.

The aim of this study is to contribute to the existing literature by analyzing the relationship between securitization and risk taking in a sample of 174 American commercial banks during the period 2001-2008. We consider two alternative measures of risk: the ratio of risk weighted assets per total assets and the $\mathrm{Z}$ score which combines capital, profitability and return volatility measures. In addition, we consider different classes of assets and examine whether different types of securitized assets lead to heterogeneous effects on banking stability.

The paper proceeds as follows. In the following section, we relate the paper to the existing literature. Section 3 specifies our research methodology. Section 4 presents a discussion of our results. The final section concludes. 


\section{Review of Previous Studies}

Studies on the effects of securitization on bank's risk behavior have reached ambiguous conclusions. Specifically, we can distinguish between two views: on one hand, those in favor of a negative association between securitization and credit risk and on the other hand, those in favor of a positive association.

According to the first view, many authors such Pavel and Phillis (1987), Pennacchi (1988) and Gorton and Pennacchi (1995) argue in favor of the risk reduction and loan growth that loans sales secondary markets can provide. Indeed, by separating the origination and financing operations, loan sales help banks to reduce their credit risks, increase their lending capacities and continue to finance profitable projects when funding costs are increasing. Demzets (2000) emphasizes the diversification advantages related to loan sales markets. Also, Jiangli and Pritsker (2008) find that the securitization of mortgage loans affects negatively the insolvability risk of American bank holdings. Similarly, Casu et al. (2010) find evidence supporting the stability effect of mortgage securitization in USA.

Regarding the second view, many researchers have warning against the reverse effects that the recourse to securitization markets can lead to, both on individual and aggregated levels. Among others, Dionne and Harchaoui (2003) using a simultaneous model derived from those of Shrieves and Dahl (1992) and Aggarwal and Jacques (2001), find a positive association between securitization and bank risk in Canada.

Krahnen and Wilde (2006) applied a Capital Asset Pricing model (CAPM) to determine reactions of European banks' stock returns following the announcement of a securitization transaction and then deduced changes in their systematic risks. Specifically, their results show that the announcement of securitization have a remarkable effect on systematic risk of European banks which seem to engage in more risky activities following a securitization event.

Baur and Joossens (2006) find also evidence that securitization, by transferring risks to other market participants, reduces banks' capital requirements and leads to an increase of the systemic risk especially when correlations between market participants increase. Two cases could explain this result:

- When risks are transferred to other banks, interbank linkages increase and therefore augment systemic risks.

- When risks are transferred to other unregulated participants, capital level in the economy become insufficient to cover risk. So, banking stability decreases.

The hypothesis of a destabilizing effect of securitization was also, supported by Michalac and Uhde (2009) in the European context. Especially, their results suggest that securitization is utilized by European banks as a source of capital relief and additional funding and that both direct and indirect effect may provoke a decrease in their financial stabilities.

Similarly, Uhde and Michalac (2010) applying the event study methodology of Krahnen and Wilde (2006), report a positive effect of securitization on systematic risks of European banks. This association seems however, depending on the amount of bank's systematic risk before a securitization event and on its strategy after securitization. In fact, if the bank reinvests its capital into risky assets, the systematic risk after the securitization event must increase and vice versa.

\section{Methodology}

\subsection{Sample}

Our empirical study focused on a sample of 174 American commercial banks having made at least one securitization transaction during the period from June 2001 until December 2008. This choice is conducted by the availability of securitization data. In fact, since June 2001, American banks have been required to provide detailed information on their securitization activities in their balance sheets. Giving that, we collect accounting and securitization data from the « Federal Deposit Insurance Corporation (FDIC) » database. For macro-economic data, we extract them from the World Bank database.

\subsection{Definition and Measurement of the Variables}

To explain bank risk taking behavior, we consider four types of variables: variables reflecting the securitization activity of the banks, bank specific variables related to the financial characteristics of the banks, macro-economic variables reflecting the economic environment of the banks as well as control variables. Notes on variables are presented in table 1 .

Insert Table 1 Here

Table 2 reports descriptive statistics for the entire set of included variables.

Insert Table 2 Here 


\subsubsection{The Dependent Variable: Credit Risk}

We employ two measures for credit risk: the ratio of risk weighted assets to total assets (RWATA) and the Z score. The first one captures the allocation of assets between different categories of risks. The second measure proposed by Roy (1952) and used by Goyeau and Tarazi (1992), Boyd et al. (2006), Laeven and Levine (2006) and Uhdle and Heimeshoff (2009), indicates the distance from insolvability. So, a higher value of $Z$ score indicates a little default risk. Mathematically, $\mathrm{Z}$ score can be denoted as follows:

$$
\text { Zscore }_{i t}=\frac{R O A A_{i t}+E_{i t} / A_{i t}}{\sigma\left(\text { ROAA }_{i t}\right)}
$$

We define ROAA as the average return on assets, E/A as the capital ratio and $\sigma(\mathrm{ROAA})$ as the volatility of the average return on assets.

\subsubsection{The Independent Variables}

\subsubsection{Credit Risk Securitization}

Following Berger and Udell (1993), Dionne and Harchaoui (2003) and Casu et al. (2010), we approximate the securitization activity (TSECTA) using the ratio of the total securitized assets to total assets. Also, we distinguish between two classes of securitized assets and calculate: the ratio of mortgage securitized assets to total assets (MBSTA) and the ratio of non mortgage securitized assets to total assets (OSECTA).

Previous studies have not found any conclusive results about the relationship between securitization and bank credit risk. As explained by Gorton and Pennacchi (1995) and Wagner (2007), securitization allows on one hand, banks to reduce their credit risks by transferring them out of their balance sheets. On the other hand, it encourages banks to increase their risk taking by investing in more risky assets. Therefore, we can anticipate a positive or a negative coefficient on this variable.

\subsubsection{Bank Specific Variables}

\subsection{Capital}

We measure bank capital using the total capital (TCAP) and the capital per total assets (CAPTA) ratios. The first one measured by the ratio of equity capital to risk weighted assets, captures the level of bank's capital related to its risks. The second ratio measures however, the absolute level of bank's capital.

According to the literature, there isn't a consensus regarding the effects of capital on bank risk taking behavior. For example, Koehn and Santomero (1980) and Kim and Santomero (1988) find that banks with high capital ratios compared to regulatory standards can increase their risk taking by investing in more risky activities. However, Rochet (1992) shows that banks can behave with aversion towards risk after an increase of their capital levels. Therefore, we can anticipate a positive or a negative effect of this variable on bank risk.

\subsection{Liquidity}

We measure bank liquidity by the ratio of liquid assets to total assets (LIQATA) used by Kashyap and Stein (2000), Goderis et al. (2007) and Loutskina (2011). Traditionally, a reduction of liquidity forces banks to restrain their loan supply and reduce their risk taking. The development of securitization has however, provided banks (notably the less liquid ones) with new alternative funds making thus, the relationship between liquidity and bank risk very ambiguous.

\subsection{Performance}

We employ return on equity (ROE) as a proxy of bank performance. Following the argument that poor performing banks might increase their risk taking to re-establish their profitability levels, we can expect a negative coefficient on this variable.

\subsection{Size}

We approximate size variable by the natural logarithm of total assets (LOGTA). Particularly, one could argue that large banks have better diversification opportunities than small banks. Following this argument, we expect a negative correlation between size and credit risk.

\subsubsection{Macro-economic variables}

\subsection{Concentration:}

We measure banking market concentration by the Herfindahl Hirschmann index (HHI) computed as the sum of squared market shares of all banks. Mathematically, HHI can be noted as follows: 
We define $\mathrm{S}_{\mathrm{i}}$ as the market share of the bank $\mathrm{i} . \quad H H I=\sum_{k=0}^{174} S_{i}^{2}$

Previously empirical studies have concluded to mixed results about the relationship between market structure and bank risk: While Keeley (1990), Helmann et al. (2000), Repullo (2004), Levy-yeyati and Micco (2007) and Delis and Pasiouras (2009) were arguing in favor of a destabilizing effect of competition, many other authors such Boyd and De Nicolo (BDN 2005), Boyd et al. (2006) and De Nicolo and Loukoinova (2007) showed that banks become more risky as their markets become more concentrated. Therefore, we can expect an ambiguous effect for the HHI variable.

\subsection{Real Interest Rate}

We introduced interest rate (RINT) to take into account the effect of interest rates on bank risk taking behavior. Empirically, the literature suggests that increasing interest rates make loan repayment more difficult for borrowers which may result in high loan default rates and decreasing asset quality for the bank. Following this argument, we can expect a negative coefficient on this variable.

\subsection{Inflation}

We further introduced the level of inflation deflated by the GDP (INF). According to Hortlund (2005), its effect depends on the net effect of interest margin and financing costs which tend in general, to increase during inflation periods. Therefore, we can expect an ambiguous effect of the INF variable on bank risk.

\subsubsection{Control Variable (Dummy)}

In order to take into account the recent financial disturbances which have occurred since June 2007, we introduced a control variable (Dummy) which takes 1 during the crisis period (from June 2007 until December 2008) and 0 before that (from June 2001 until June 2007).

\subsection{Model}

To analyze the effect of securitization on credit risk of American commercial banks and verify the validity of our hypothesis, we will use the specification of a linear model which relates credit risk to a set of independent variables among them the securitization. Mathematically, our theoretical model can be written as follows:

$$
R \text { WATA }_{i t}=\text { A TSECTA }_{i t}+\sum_{j=1}^{k} B_{j} X_{i t}+C+\mu_{i t}
$$

Where,

RWATA: Bank credit risk measured by the ratio of risk weighted assets to total assets.

TSECTA: Ratio of total securitized assets to total assets.

$\mathrm{X}$ : Vector of the independent variables representing bank specific and macro-economic specificities of bank $\mathrm{i}$ for the quarter $t$.

$\mathrm{A}, \mathrm{B}_{\mathrm{j}}$ et $\mathrm{C}$ : Parameters to be estimated.

$\mu$ : Error term.

Alternatively, we will consider another proxy of credit risk: the $\mathrm{Z}$ score. For this variable, we will also, test for different types of underlined assets, the effects of securitization on bank stability. The basic regression can be written as follows:

$$
\text { Zscore }_{i t}=A^{\prime} \operatorname{TSECTA}_{i(t-1)}+\sum_{j=1}^{k} B_{j}^{\prime} X_{i t}^{\prime}+C^{\prime}+\mu_{i t}^{\prime}
$$

Where,

Z score: Bank stability.

TSECTA: Ratio of total securitized assets to total assets. Also, we will consider the ratio of mortgage securitized assets to total assets (MBSTA) and the ratio of non mortgage securitized assets to total assets (OSECTA).

$\mathrm{X}^{\prime}$ : Vector of the independent variables representing bank specific and macro-economic specificities of bank i for the quarter $\mathrm{t}$.

$A^{\prime}, B_{j}^{\prime}$ et $C^{\prime}$ : Parameters to be estimated. 
$\mu^{\prime}$ : Error term.

The estimation of these models is realized by the Generalized Least Squared method. This choice is justified by the results of the specification tests carried out via the STATA software.

\section{Results and Interpretations}

In this section, we will continue with an analysis of the multicollinearity and the specification tests, and a discussion of the results of our estimations.

\subsection{Multicollinearity Matrix}

By examining Pearson correlation matrix, we observe that some variables_RWATA and TCAP, TSECTA and MBSTA and HHI and RINT are strongly correlated (with a correlation coefficient higher than the critical value of 0.7). This indicates according to Kervin (1992), the existence of multicollinearity among them. Thus, these variables must not be included simultaneously in the same model. Also, we observe that the other independent variables are weakly correlated, allowing to exclude the possibility of an overlap of their significance in a multivariate model.

Insert Table 3 Here

\subsection{Specification Tests}

We chose to estimate two specifications of the model I. In the first one, we introduced securitization and bank specific variables. In the second, we added variables related to macro-economic conditions such as concentration and inflation as well as control variable. Concerning the model II, we also, consider two specifications depending on whether we take into account the inflation rates effects on bank stability or not.

The table 4 reports the results of the specification tests.

\section{Insert Table 4 Here}

For each model, we firstly, tested the presence of individual effects. Based on the Fischer test, we show the presence of specific individual effects, which justifies the recourse to panel data. Then, we turned to determine the nature of these specific effects via the Hausman test (1978). This test clearly accepts the panel estimation with fixed specific effects against the random effects specification $(\mathrm{p}$-value $=0.000)$.

Finally, we moved to detect the existence of heteroscedasticity and autocorrelation problems. In particular, the tests of Breuch and Pagan and wald modified show that we cannot accept the nul hypothesis of homoscedasticity for the different models $(p$-value $=0.000)$. Regarding autocorrelation, the Wooldridge test reveals that we have to reject the nul hypothesis of the absence of autocorrelation ( $p$-value $=0.000$ ). In other words, we support the presence of an autocorrelation problem of order 1 between errors.

\subsection{Estimation results}

\subsubsection{Impact of Securitization On Bank's Credit Risk}

Estimation results corrected from heteroscedasticity and autocorrelation problems are reported in table 5.

\section{Insert Table 5 Here}

The measurement of the total significance of the model was carried out by several criteria among which the value of wald chi 2 and $\mathrm{R}^{2}$. Table 5 shows that the wald chi2 test has a value of (4466.80) in model I.1 and (4544.12) in model I.2, which are significant to $1 \%$ level. Also, $\mathrm{R}^{2}$ within which gives an idea on the variability share of the credit risk variable explained by the other independent variables is respectively $(0.3248)$ and $(0.4035)$. This shows a mean quality of adjustment between banks. In the other hand, it justifies the addition of the variables related to macro-economic conditions to improve the robustness of the model.

According to our hypothesis, we report a positive and significant impact of TSECTA on bank's credit risk. In other words, a greater recourse to securitization is associated with a deterioration in the quality of American banks' loan portfolios and an increase of the credit risk in their balance sheets. Especially, our results suggest that an increase of the volume of securitized assets per total assets by $100 \%$ leads to an increase of the volume of risk weighted assets per total assets by $3.9 \%$ (6.6\% when referring to the model I.2), all things being equal.

These results allow us to support a reversal effect of securitization in the management of credit risk. In fact, American banks that are very active in this market seem to reduce their risk aversion by holding more risky assets. We join thus, the results of Dionne and Harchaoui (2003) for the Canadian banks. Jiangli and Pritsker (2008) and Casu et al. (2010) have in contrast, supported a stabilizing effect of securitization techniques in the American banking system.

This positive association between securitization and credit risk can be explained as follows: 
- If securitization is made without recourse, a positive association will be justified either by the reduction of the borrowers' selection efforts from banks as described by Gorton and Pennacchi (1995) or the reduction of their monitoring incentives as suggested by Gorton and Pennacchi (1995), Morisson (2003) and Wagner and Marsh (2006).

- If securitization is made with recourse, selection and monitoring motivations of banks were thus maintained. So, an increase of credit risk can be explained following Dionne and Harchaoui (2003), by the securitization by American banks of their safe assets; retaining thus, in their balance sheets the riskiest ones.

Credit risk seems also to be affected by the regulatory capital level. In fact, our results show a negative and very significant relationship between TCAP and RWATA.

Similarly, liquidity has a negative and significant effect on credit risk. In average, less liquid banks have taken more risks during the period 2001-2008. When relating this result to our context, this negative association between the holding of liquidity and bank risk taking can be explained in accordance to Loutskina (2011), by the role of securitization as an alternative funding source. Obviously, the availability of liquidity through securitization provides banks (e.g. the less liquid ones) with alternative funds, which lead them to involve in more risky assets.

Paradoxically, the effect of ROE is positive and very significant. In other words, the most profitable banks are also the most risky.

The coefficient related to LOGTA is also, positive and significant. The portfolio composition seems to turn to more risky branches when bank size increases. This contradicts the hypothesis of diversification advantages of large banks as advanced by Demsetz and Strahan (1997). It can however, be explained according to Petey (2004) by the specialization of the American largest banks in some branches of the lending market.

With regard to macro-economic conditions, the one period lagged HHI variable shows, conforming to our hypothesis, a positive and significant coefficient. This means that banks become more risky as their markets become more concentrated. To explain this idea, Boyd and De Nicolo (BDN, 2005), Boyd et al. (2006), Beck et al. (2006) and De Nicolo and Loukoianova (2007) argue that market concentration leads banks to charge high interest rates on their loans, which can increase borrowers' default risk and in consequence, the number of non performing loans in the banks' portfolios.

Also, INF shows a positive and significant impact on credit risk. For example, an increase of inflation rates by 100 base points is associated with an increase of credit risk by $0.271 \%$, all things being equal. This finding can be explained as follows: As interest rates tend to increase in inflation periods, this encourages banks to engage in risky portfolios in order to profit from the new investment opportunities. At the same time, an increase in interest rates makes loan repayment more difficult for borrowers leading thus, to a deterioration in the quality of banks' loan portfolios and an increase in credit risk in their balance sheets.

Finally, we observe that the coefficient of the Dummy variable is positive which indicates that the credit risk of American banks has increased during the subprime period.

\subsubsection{Impact of Securitization on Banking Stability}

\subsubsection{Total Volume of Securitization and Banking Stability}

We turn now, to analyze the effect of securitization on American banking stability. The results of the different estimations are summarized in table 6 .

\section{Insert Table 6 Here}

As we can notice, the two models produce similar results. We proceed then, to choose between these models based on the information criteria of Akaike (AIC) and Schwartz (BIC). By definition, the most adequate model is the one that minimizes these two information criteria. The table 7 shows that the model II.2 is the most appropriate one.

\section{Insert Table 7 Here}

Thus, we will focus our interpretations on the results issued from the model II.2. In particular, we can observe that the effect of RWATA is negative. This means that bank's stability decreases when its portfolio becomes more risky.

Based on this result, we can expect that the securitization, by increasing the volume of risky assets on bank's balance sheet reduces its stability level. Surprisingly, our results show that the effect of the one period lagged TSECTA is significantly positive supporting thus, a stabilizing effect of securitization for American commercial banks. 
This seems to be in contradiction with our prior conclusions obtained from the first measure of credit risk (RWATA). We think that this paradox is related to the fact that different classes of securitized assets lead to heterogeneous effects on banking stability.

The coefficient of CAPTA is significantly positive. This means that American overcapitalized banks appear in average, more stable. This result corroborates our first affirmations and justifies thus, the reinforcement of capital requirements efforts made by regulatory authorities to support banking stability.

ROE variable shows also, a positive and significant impact on $\mathrm{Z}$ score suggesting thus, a great stability of the most profitable American banks.

However, LIQATA variable reports a negative effect on $\mathrm{Z}$ score. This means that less liquid banks are less prone to insolvability problems. This can be explained by the new funding possibilities that less liquid banks can obtain through securitization. In fact, the recourse to these markets provides banks with additional funding sources that help them to fulfill their funding needs, to take more easily new profitable investment opportunities and to increase their stability levels.

The coefficient related to LOGTA appears also, negative and significant. This indicates that large banks are in average less stable than small banks. As explained before, the specialization of large banks on some credit market branches and the resulted risk concentration lead to a destabilizing effect on American banks.

The effect of the one period lagged RINT variable is significantly positive. This can be attributed to the fact that an increase in real interest rates increases bank profit margins and improves thus, their stability levels.

\subsubsection{Nature of the Underlying Assets and Banking Stability}

In order to best understand interactions between securitization and banking stability, we chose to push more our analysis by considering different classes of securitized assets (e.g. securitization of mortgage assets Vs securitization of non mortgage assets). The results of our estimations are reported in table 8.

Insert Table 8 Here

As predicted, different forms of securitization seem to have heterogeneously effects on American banks' stabilities: whereas mortgage securitization (MBSTA) reinforces banking stability, securitization of non mortgage loans (OTSECTA) leads on the contrary, to reversal effects.

Focused firstly on mortgage securitization, our empirical results confirm the advantages of this type of securitization on banking stability. This can be explained following Casu et al. (2010), by the implicit recourse provided in mortgage securitization transaction. In fact, for this type of securitization the risk is not totally transferred to investors but maintained by the securitizer bank in its off-balance sheet engagements. This risk retention characterizing mortgage securitization transactions provides thus, a mean to maintain banks' incentives to monitor their borrowers and avoid in consequence, the reversal effects that securitization can have on banking stability.

Paradoxically, non mortgage securitization appears more risky. In fact, our results indicate that American commercial banks that are most involved in non mortgage securitization markets are less stable than less involved ones. For illustration, an increase in the volume of non mortgage securitized assets per total assets by $1 \%$ is associated with a decrease in banking stability by $6.8 \%(7 \%$ when we refer to the results of the model II.5). We join thus, the conclusions of Krahnen and Wilde (2006), Baur and Joossens (2006), Michilak and Uhde (2009) and Uhde and Michilak (2010) having also, reported an increase in systematic risk of European banks after a securitization transaction. Therefore, we conclude that the net effect of securitization on bank stability will depend on the structure of the securitized portfolio and the credit support provided by the bank.

\section{Conclusion}

The object of this study was to investigate the effects of securitization on the credit-risk taking behavior of banks. Based on a sample of 174 US commercial banks during the period 2001-2008, we report an increase of the credit risk of American banks when they securitize their loans. This doesn't however, mean that these banks become less stable. In fact, our results suggest, contrary to what one could pretend, a positive and significant impact of securitization on banking stability.

We attribute this paradox to the fact that different classes of securitized assets lead to heterogeneous effects on American banks' risk. Indeed, our results show that mortgage securitization has a positive and significant impact on banking stability, providing thus a support to the implicit recourse hypothesis. Inversely, non mortgage securitization has a negative effect on banking stability because of the reduction of banks' monitoring incentives related to this particular form of securitization. Therefore, the net effect of securitization on bank stability will depend on the structure of the securitized portfolio and the credit support provided by the bank. 


\section{Acknowledgements}

We would like to thank Pr. Nadia Massoud from the Schulich School of Business for helping us to obtain the data.

\section{References}

Aggarwal, R., \& Jacques, K. T. (2001). The impact of FDICIA and prompt corrective action on bank capital and risk: Estimates using simultaneous equations model. Journal of Banking and Finance, 25, 1139-1160. http://dx.doi.org/10.1016/S0378-4266(00)00125-4

Baur, D., \& Joossens, E. (2006). The effect of credit risk transfer on financial stability. EUR Working Paper No 21521 EN. http://dx.doi.org/10.2139/ssrn.881774

Beck, T., Demirguç-Kunt, A., \& Levine, R. (2006). Bank concentration, competition and crises: First results, Journal of Banking and Finance, 30, 1581-1603. http://dx.doi.org/10.1016/j.jbankfin.2005.05.010

Berger, A. N., \& Udell, G. (1991). Securitization, risk and the liquidity problem in banking. Finance and Economic Discussion Series No181, Board of Governors of the Federal Reserve System. [Online] Available: http://www.federalreserve.gov/pubs/feds/fedsorder.html

Boyd, J. H., \& De Nicolo, G. (2005). The theory of bank risk taking and competition revisited. Journal of Finance, 60, 1329-1343. [Online] Available: http://www.blackwell-synergy.com/doi/abs/10.1111/j.1540-6261.2005.00763.x

Boyd, J. H., De Nicolo, G., \& Jalal, A. M. (2006). Bank risk-taking and competition revisited: New theory and new evidence. IMF Working Paper, No 06/297, December 2006. [Online] Available: http://www.imf.org/external/pubs/ft/wp/2006/wp06297.pdf

Casu, B., Clare, A., Sarkisyan, A., \& Thomas S. (2010). Does securitization reduce credit risk taking? Empirical evidence from US bank holding companies. Working Paper Series No 02/10, City University London. [Online] Available: http://www.cass.city.ac.uk/_data/assets/pdf_file/0003/77826/CBR_WP02-10.pdf

Cebenoyan, A. S., \& Strahan, P. E. (2004). Risk management, capital structure and lending at banks. Journal of Banking and Finance, 28, 19-43. http://dx.doi.org/10.1016/S0378-4266(02)00391-6

De Nicolo, G., \& Loukoianova, E. (2007). Bank ownership, market structure and risk. IMF Working Paper No 07/215, September 2007. [Online] Available: http://www.imf.org/external/pubs/ft/wp/2007/wp07215.pdf

Demsetz, R. S. (2000). Bank loan sales: A new look at the motivations for secondary market activity. Journal of Financial Research, 23, 197-222. [Online] Available: http://www.blackwellpublishing.com/journal.asp?ref=0270-2592

Demsetz, R. S., \& Strahan P. E. (1997). Diversification, size and risk at bank holding companies. Journal of Money, Credit and Banking, 29, 300-313. [Online] Available: http://www.blackwellpublishing.com/journal.asp?ref=0022-2879

Dionne, G., \& Harchaoui T. M. (2003). Banks' capital, securitization and credit risk: An empirical evidence for Canada. HEC Working Paper, No 03-01. http://dx.doi.org/10.2139/ssrn.369501

Goderis, B., Marsh, I. W., Castello, J. V., \& Wagner, W. (2007). Bank behaviour with access to credit risk transfer markets. Bank of Finland Research Discussion Paper, No 4/2007. http://dx.doi.org/10.2139/ssrn.1010101

Gorton, G. B., \& Pennacchi, G. G. (1995). Banks and loan sales: Marketing nonmarketable assets. Journal of Monetary Economics, 35, 389-411. http://dx.doi.org/10.1016/0304-3932(95)01199-X

Goyeau, D., \& Tarazi, A. (1992). Évaluation du risque de défaillance bancaire en Europe. Revue d'Economie Politique, 102, 249-280. [Online] Available: http://dialnet.unirioja.es/servlet/articulo?codigo=2925352

Hausman, J. A. (1978). Specification tests in econometrics. Econometrica, 46, 1251-1271. [Online] Available: http://www.jstor.org/pss/1913827

Hortlund, P. (2005). Do inflation and high taxes increase bank leverage. SSE/EFI Working Paper Series in Economics and Finance, No 612, November $2005 . \quad$ [Online] Available: http://swopec.hhs.se/hastef/papers/hastef0612.pdf

Instefjord, N. (2005). Risk and hedging: Do credit derivatives increase bank risk. Journal of Banking and Finance, 29, 333-345. http://dx.doi.org/10.1016/j.jbankfin.2004.05.008

Jiangli, W., \& Pritsker, M. (2008). The impacts of securitization on US bank holding companies. http://dx.doi.org/10.2139/ssrn.1102284 
Kashyap, A., \& Stein, J. (2000). What do a million observations on banks say about the transmission of monetary policy. American Economic Review, 90, 407-428. [Online] Available: http://www.nber.org/papers/w6056.pdf

Kervin, J. B. (1992). Methods for business research. Harpercollins College Div, January 1992.

Kim, D. \& Santomero, A. M. (1988). Risk in banking and capital regulation. Journal of Finance, 43, 1219-1233. [Online] Available: http://www.jstor.org/pss/2328216

Koehn, M., \& Santomero, A. M. (1980). Regulation of bank capital and portfolio risk. Journal of Finance, 35, 1235-1244. [Online] Available: http://web.cenet.org.cn/upfile/12826.pdf

Krahnen, J. P., \& Wilde, C. (2006). Risk Transfer with CDOs and Systemic Risk in Banking. CFS Working Paper No 2006/04. http://dx.doi.org/10.2139/ssrn.889541

Laeven, L., \& Levine, R. (2008). Bank governance, regulation and risk-taking. NBER Working Paper No 14113, June 2008. [Online] Available: http://www.nber.org/papers/w14113.pdf

Loutskina, E. (2011). The role of Securitization in bank liquidity and funding management. Journal of Financial Economics, 100, 663-684. http://dx.doi.org/10.1016/j.jfineco.2011.02.005

Michalak, T. C., \& Uhde, A. (2009). Credit Risk Securitization and Banking Stability: Evidence from the Micro-Level for Europe. 22nd Australasian Finance and Banking Conference 2009. [On line] Available: http://apps.olin.wustl.edu/FIRS/pdf/MemberPapers/258/28.pdf

Morrison, A. D. (2003). Credit derivatives, disintermediation and investment decisions. [Online] Available: http://users.ox.ac.uk/ bras0541/monitoringcds11.pdf

Pavel, C., \& Phillis, D. (1987). Why commercial banks sell loans: An empirical analysis. Economic perspectives of the Federal Reserve Bank of Chicago, 3-14. [Online] Available: http://www.chicagofed.org/digital_assets/publications/economic_perspectives/1987/ep_may_jun1987_part1_pavel.p $\mathrm{df}$

Pennacchi, G. G. (1988). Loan sales and the cost of bank capital. Journal of Finance, 43, 375-396. [Online] Available: http://www.jstor.org/pss/2328466

Petey, J. (2004). Les déterminants du risque d'insolvabilité dans l'industrie bancaire: Une approche en termes de frontière de production. Louvain Economic Review, 70, 401-424. [Online] Available : http://sites.uclouvain.be/econ/DP/REL/2004041.pdf

Rochet, J. C. (1992). Capital Requirements and the behaviour of commercial banks. European Economic Review, 36, 1137-1170. http://dx.doi.org/10.1016/0014-2921(92)90051-W

Roy, A. D. (1952). Safety first and the holding of assets. Econometrica, 20, 431-449. [Online] Available: http://www.jstor.org/pss/1907413

Santomero, A. M., \& Trester, J. J. (1998). Financial innovation and bank risk taking. Journal of Economic Behavior and Organization, 35, 25-37. http://dx.doi.org/10.1016/S0167-2681(97)00103-0

Securities Industry and Financial Market Association. 2011. Securitization report 2011. [Online] Available: http://www.sifma.org

Shrieves, R. E., \& Dahl, D. (1992). The relationship between risk and capital in commercial banks. Journal of Banking and Finance, 16, 439-457. http://dx.doi.org/10.1016/0378-4266(92)90024-T

Stock, J. H., \& Watson, M. W. (2002). Has the business cycle changed and why. NBER Working Paper No 9127. [Online] Available: http://www.nber.org/papers/w9127.pdf

Uhde, A., \& Heimeshoff, U. (2009). Consolidation in banking and financial stability in Europe: Empirical evidence. Journal of Banking and Finance, 33, 1299-1311. http://dx.doi.org/10.1016/j.jbankfin.2009.01.006

Uhde, A., \& Michalak, T. C. (2010). Securitization and systematic risk in European banking: Empirical evidence. Journal of Banking and Finance, 34, 3061-3077. http://dx.doi.org/10.1016/j.jbankfin.2010.07.012

Van Roy, P. (2005). The impact of the 1988 Basel Accord on banks' capital ratios and credit risk-taking: An international study. EFMA 2004 Basel Meetings. http://dx.doi.org/10.2139/ssrn.497264

Wagner, W. (2007). The liquidity of bank assets and banking stability. Journal of Banking and Finance, 31, 121-139. http://dx.doi.org/10.1016/j.jbankfin.2005.07.019

Wagner, W., \& Marsh I. W. (2006). Credit risk transfer and financial sector stability. Journal of Financial Stability, 2, 173-193. http://dx.doi.org/10.1016/j.jfs.2005.11.001 
Table 1. Definition of Variables

\begin{tabular}{|c|c|c|c|c|c|}
\hline \multicolumn{2}{|c|}{ Variables } & \multicolumn{2}{|c|}{ Designation } & Description & $\begin{array}{c}\text { Expected Sign on } \\
\text { RC }\end{array}$ \\
\hline \multicolumn{6}{|c|}{ Dependent Variables : } \\
\hline \multicolumn{2}{|l|}{ Credit Risk } & $\mathrm{RC}$ & $\begin{array}{l}\text { RWATA } \\
\text { Z Score }\end{array}$ & \multicolumn{2}{|c|}{$\begin{array}{l}\text { Risk weighted assets/total assets } \\
\text { The sum of the return on average assets (ROAA) and equity capital to total assets to } \\
\text { standard deviation of ROAA. }\end{array}$} \\
\hline \multicolumn{6}{|c|}{ Independant Variables : } \\
\hline & Securitization & \multicolumn{2}{|c|}{$\begin{array}{l}\text { TSECTA } \\
\text { MBSTA } \\
\text { OSECTA }\end{array}$} & $\begin{array}{l}\text { Total securitized assets/total assets } \\
\text { Mortgage securitized assets/total assets } \\
\text { Non mortgage securitized assets/total assets }\end{array}$ & $\begin{array}{l}(+/-) \\
(+/-) \\
(+/-) \\
\end{array}$ \\
\hline \multirow{4}{*}{ 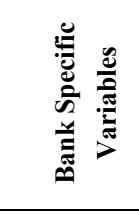 } & Capital & \multicolumn{2}{|c|}{$\begin{array}{l}\text { TCAP } \\
\text { CAPTA }\end{array}$} & $\begin{array}{l}\text { Equity capital/risk weighted assets } \\
\text { Equity capital/total assets }\end{array}$ & $\begin{array}{l}(+/-) \\
(+/-)\end{array}$ \\
\hline & Liquidity & \multicolumn{2}{|c|}{ LIQATA } & Liquid assets /total assets & $(+/-)$ \\
\hline & Performance & \multicolumn{2}{|c|}{ ROE } & Net income/equity capital & $(-)$ \\
\hline & Size & \multicolumn{2}{|c|}{ LOGTA } & Logarithm of total assets & $(-)$ \\
\hline \multirow{3}{*}{ 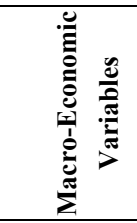 } & Concentration & \multicolumn{2}{|c|}{$\mathrm{HHI}$} & Sum of squared market shares of all banks & $(+/-)$ \\
\hline & $\begin{array}{l}\text { Real interest } \\
\text { rate }\end{array}$ & \multicolumn{2}{|c|}{ RINT } & $\begin{array}{l}\text { Lending interest rate adjusted for inflation as measured by the Gross } \\
\text { Domestic Product deflator }\end{array}$ & $(-)$ \\
\hline & Inflation & \multicolumn{2}{|l|}{ INF } & Inflation deflated by the Gross Domestic Product & $(+/-)$ \\
\hline \multicolumn{6}{|c|}{ Control Variable: } \\
\hline & $\begin{array}{l}\text { Subprime } \\
\text { Crisis }\end{array}$ & \multicolumn{2}{|c|}{ Dummy } & $\begin{array}{l}=0: \text { before crisis } \\
=1: \text { after crisis }\end{array}$ & $(+)$ \\
\hline
\end{tabular}

Table 2. Descriptive Statistics

\begin{tabular}{llllll}
\hline Variables & Mean & $\begin{array}{c}\text { Standard } \\
\text { Deviation }\end{array}$ & Minimum & Maximum & $\begin{array}{c}\text { Number of } \\
\text { observations }\end{array}$ \\
\hline RWATA & 0.696 & 0.129 & 0.239 & 0.993 & 5394 \\
Z Score & 33.288 & 15.949 & 1.202 & 191.113 & 5394 \\
TSECTA & 0.017 & 0.061 & 0 & 0.726 & 5394 \\
MBSTA & 0.013 & 0.056 & 0 & 0.723 & 5394 \\
OSECTA & 0.004 & 0.021 & 0 & 0.231 & 5394 \\
TCAP & 0.149 & 0.056 & 0.049 & 0.489 & 5394 \\
CAPTA & 0.097 & 0.027 & 0.025 & 0.261 & 5394 \\
LIQATA & 0.078 & 0.079 & 0.002 & 0.642 & 5394 \\
ROE & 0.067 & 0.058 & -0.711 & 0.451 & 5394 \\
LOGTA & 13.137 & 2.237 & 9.256 & 21.110 & 5394 \\
HHI & 0.154 & 0.007 & 0.144 & 0.170 & 5394 \\
RINT & 0.032 & 0.012 & 0.014 & 0.052 & 5394 \\
INF & 0.026 & 0.005 & 0.017 & 0.033 & 5394 \\
Dummy & 0.258 & 0.438 & 0 & 1 & 5394 \\
\hline
\end{tabular}


Table 3. Pearson Correlation Matrix




Table 4. Specification Tests

\begin{tabular}{|c|c|c|c|c|c|c|c|c|}
\hline & \multicolumn{2}{|c|}{ Model I.1 } & \multicolumn{2}{|c|}{ Model I.2 } & \multicolumn{2}{|c|}{ Model II.1 } & \multicolumn{2}{|c|}{ Model II.2* } \\
\hline & $\begin{array}{c}\text { Fisher } \\
\text { (p-value) }\end{array}$ & $\begin{array}{c}\text { Chi2 } \\
\text { (p-value) }\end{array}$ & $\begin{array}{c}\text { Fisher } \\
\text { (p-value) }\end{array}$ & $\begin{array}{c}\text { Chi2 } \\
\text { (p-value) }\end{array}$ & $\begin{array}{c}\text { Fisher } \\
\text { (p-value) }\end{array}$ & $\begin{array}{c}\text { Chi2 } \\
\text { (p-value) }\end{array}$ & $\begin{array}{c}\text { Fisher } \\
\text { (p-value) }\end{array}$ & $\begin{array}{c}\text { Chi2 } \\
\text { (p-value) }\end{array}$ \\
\hline \multirow[t]{3}{*}{ Fisher Test } & $\mathrm{F}(173,5216)$ & & $\mathrm{F}(173,5212)$ & & $F(173,5039)$ & & $\mathrm{F}(173,5038)$ & \\
\hline & $=144.82$ & & $=161.38$ & & $=49.86$ & & $=49.99$ & \\
\hline & $(0.000)$ & & $(0.000)$ & & $(0.000)$ & & $(0.000)$ & \\
\hline \multirow[t]{3}{*}{ Hausman Test $* *$} & & Chi2(4) $=$ & & Chi2(8) $=$ & & Chi2(7) $=$ & & $\operatorname{Chi} 2(8)=$ \\
\hline & & 54.99 & & 52.72 & & 56.89 & & 42.62 \\
\hline & & $(0.000)$ & & $(0.000)$ & & $(0.000)$ & & $(0.000)$ \\
\hline \multicolumn{9}{|c|}{ Heteroscedasticity tests } \\
\hline \multirow{3}{*}{$\begin{array}{l}\text { Breuch et Pagan } \\
\text { test }\end{array}$} & & Chi2(1) & & Chi2(1) & & Chi2(1) & & Chi2(1) \\
\hline & & $=1790.01$ & & $=39706.91$ & & $=2224.91$ & & $=2194.00$ \\
\hline & & $(0.000)$ & & $(0.000)$ & & $(0.000)$ & & $(0.000)$ \\
\hline \multirow{3}{*}{$\begin{array}{l}\text { Wald modified } \\
\text { Test }\end{array}$} & & Chi2(174) & & Chi2(174) & & Chi2(174) & & Chi2(174) \\
\hline & & $=96449.26$ & & $=1.110^{5}$ & & $=1.210^{5}$ & & $=1.210^{5}$ \\
\hline & & $(0.000)$ & & $(0.000)$ & & $(0.000)$ & & $(0.000)$ \\
\hline \multicolumn{9}{|c|}{ Autocorrelation test } \\
\hline \multirow[t]{3}{*}{ Wooldridge Test } & $F(1,173)$ & & $F(1,173)$ & & $F(1,173)$ & & $F(1,173)$ & \\
\hline & $=210.043$ & & $=210.097$ & & $=732.116$ & & $=732.316$ & \\
\hline & $(0.000)$ & & $(0.000)$ & & $(0.000)$ & & $(0.000)$ & \\
\hline
\end{tabular}

Table 5. Effect of securitization on the credit risk taking of American commercial banks

\begin{tabular}{|c|c|c|c|c|}
\hline \multicolumn{5}{|c|}{ Dependant Variable : RWATA } \\
\hline \multirow[t]{2}{*}{ Variables } & \multicolumn{2}{|c|}{ Model I.1 } & \multicolumn{2}{|c|}{ Model I.2 } \\
\hline & Coeff & S.E & Coeff & S.E \\
\hline TSECTA & $0.039(* * *)$ & 0.012 & $0.066(* * *)$ & 0.013 \\
\hline TCAP & $-1.264(* * *)$ & 0.028 & $-1.250(* * *)$ & 0.027 \\
\hline LIQATA & $-0.418(* * *)$ & 0.009 & $-0.420(* * *)$ & 0.009 \\
\hline ROE & & & $0.012(* *)$ & 0.005 \\
\hline LOGTA & $0.003(* * *)$ & 0.001 & $0.003(* *)$ & 0.001 \\
\hline L.HHI & & & $0.267(* * *)$ & 0.060 \\
\hline INF & & & $0.271(* *)$ & 0.110 \\
\hline Dummy & & & $0.006(* * *)$ & 0.001 \\
\hline Constant & $0.876(* * *)$ & 0.017 & $0.825(* * *)$ & 0.018 \\
\hline Number of Observations & \multicolumn{2}{|c|}{5394} & \multicolumn{2}{|c|}{5220} \\
\hline Wald chi2 & \multicolumn{2}{|c|}{$4466.80(* * *)$} & \multicolumn{2}{|c|}{$4544.12(* * *)$} \\
\hline $\mathbf{R 2}$ & \multicolumn{2}{|c|}{0.3248} & \multicolumn{2}{|c|}{0.4035} \\
\hline \multicolumn{5}{|c|}{$\begin{array}{l}\text { Were reported in this table, the coefficients of the linear estimation and the standard errors related to each included } \\
\text { variable. }\end{array}$} \\
\hline \multicolumn{5}{|c|}{$\begin{array}{l}\text { Variable Definition : RWATA : risk weighted assets per total assets, TSECTA : total securitized asset per total } \\
\text { assets, TCAP : total capital ratio, LIQATA : liquid assets per total assets, ROE : return on equity, LOGTA : logarithm } \\
\text { of total assets, HHI : banking concentration index, INF : inflation rate, Dummy : takes } 0 \text { before the subprime crisis and } \\
1 \text { during the subprime crisis. }\end{array}$} \\
\hline
\end{tabular}


Table 6. Effect of securitization on American banking stability

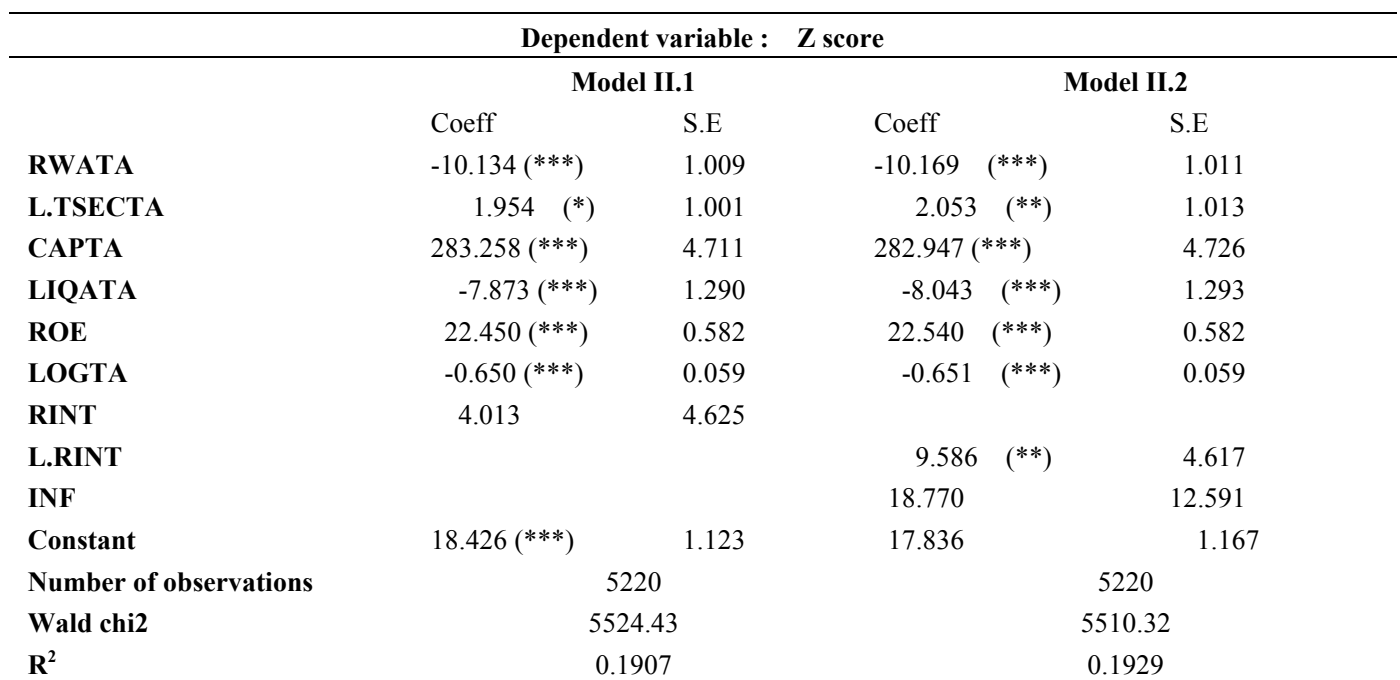

Were reported in this table, the coefficients of the linear estimation and the standard errors related to each included variable.

$* * *, * * *$ represent the significance at $1 \%, 5 \%$ and $10 \%$ levels respectively.

Variable Definition : Z score : sum of average return on assets and capital ratio per return volatility, RWATA : risk weighted assets per total assets, TSECTA : total securitized assets per total assets, CAPTA : equity capital per total assets, LIQATA : liquid assets per total assets, ROE : return on equity, LOGTA : logarithm of total assets, RINT : real interest rate, INF : inflation.

Table 7. Choice of the model

\begin{tabular}{lll}
\hline & Dependent Variable: $Z$ score \\
\hline & AIC & BIC \\
Model II.1 & 36617.32 & 36669.81 \\
Model II.2 & 36604.63 & 36663.67 \\
\hline
\end{tabular}

Table 8. Effect of securitization on American banking stability: Distinction between Mortgage securitization (MBSTA) and non mortgage securitization (OTSECTA)

\begin{tabular}{|c|c|c|c|c|c|c|}
\hline \multicolumn{7}{|c|}{ Dependent Variable : $Z$ score } \\
\hline & \multicolumn{2}{|l|}{ Model II.3 } & \multicolumn{2}{|l|}{ Model II.4 } & \multicolumn{2}{|l|}{ Model II.5 } \\
\hline & Coeff & S.E & Coeff & S.E & Coeff & S.E \\
\hline RWATA & $-10.229(* * *)$ & 1.007 & $-9.782(* * *)$ & 1.019 & $-10.081(* * *)$ & 1.012 \\
\hline L.MBSTA & $2.951(* * *)$ & 1.041 & & & $2.975(* * *)$ & 1.040 \\
\hline L.OSECTA & & & $-6.789 \quad(*)$ & 3.594 & $-7.006 \quad(*)$ & 3.605 \\
\hline CAPTA & $282.692(* * *)$ & 4.720 & $282.805(* * *)$ & 4.742 & $282.389(* * *)$ & 4.723 \\
\hline LIQATA & $-8.055(* * *)$ & 1.293 & $-7.751(* * *)$ & 1.295 & $-7.942(* * *)$ & 1.298 \\
\hline ROE & $22.537(* * *)$ & 0.583 & $22.597(* * *)$ & 0.580 & $22.587(* * *)$ & 0.584 \\
\hline LOGTA & $-0.652(* * *)$ & 0.058 & $-0.607(* * *)$ & 0.060 & $-0.631(* * *)$ & 0.060 \\
\hline L.RINT & $9.675(* *)$ & 4.621 & $9.077(* *)$ & 4.610 & $9.563 \quad(* *)$ & 4.627 \\
\hline INF & 19.015 & 12.598 & 18.344 & 12.586 & 18.786 & 12.616 \\
\hline Constant & $17.905(* * *)$ & 1.155 & $17.047(* * *)$ & 1.177 & $17.576(* * *)$ & 1.171 \\
\hline Number of observations & \multicolumn{2}{|c|}{5220} & \multicolumn{2}{|c|}{5220} & \multicolumn{2}{|c|}{5220} \\
\hline Wald chi2 & \multicolumn{2}{|c|}{$5519.57(* * *)$} & \multicolumn{2}{|c|}{$5463.25(* * *)$} & \multicolumn{2}{|c|}{$5491.33(* * *)$} \\
\hline $\mathbf{R}^{2}$ & \multicolumn{2}{|c|}{0.1933} & \multicolumn{2}{|c|}{0.1923} & \multicolumn{2}{|l|}{0.1934} \\
\hline
\end{tabular}

Were reported in this table, the coefficients of the linear estimation and the standard errors related to each included variable.

$* * *, * *, *$ represent the significance at $1 \%, 5 \%$ and $10 \%$ levels respectively.

Variables Definition: Z score: sum of average return on assets and capital ratio per return volatility, RWATA : risk weighted assets per total assets, MBSTA : mortgage securitized assets per total assets, OSECTA : non mortgage securitized assets per total assets, CAPTA : equity capital per total assets, LIQATA : liquid assets per total assets, ROE : return on equity, LOGTA : logarithm of total assets, RINT : real interest rate, INF : inflation. 


\section{Appendix 1. Construction of the variables}

\begin{tabular}{|c|c|}
\hline Variables & Code in the Call Report \\
\hline Total asset & RCFD2170 \\
\hline Total Average Asset & RCFDA224 \\
\hline Risk weighted assets & RCFDA223 \\
\hline Global volume of securitized assets & $\begin{array}{l}\text { RCFDB705+ RCFDB706+ RCFDB707+ RCFDB708+ RCFDB709+ RCFDB710+ } \\
\text { RCFDB711 }\end{array}$ \\
\hline Mortgage securitized assets & RCFDB705 \\
\hline Other securitized assets & RCFDB706+ RCFDB707+ RCFDB708+ RCFDB709+ RCFDB710+ RCFDB711 \\
\hline Capital Ratio & RCFD3210 \\
\hline Total Capital Ratio & RCFD3792 \\
\hline Liquid Assets & $\begin{array}{l}\text { Until 2001: RCFD0010+ RCFD1350+ RCFD3545 } \\
\text { From 2002: RCFD0010+ RCONB987+ RCFDB989+ RCFD3545 }\end{array}$ \\
\hline Net Income & RIAD4340 \\
\hline
\end{tabular}

* Significance of the codes was obtained from the « Consolidated financial statement for commercial banks (2001-2008)» provided by «The Bord Governers of The Federal Reserve System ».

\section{Notes:}

1- The Securitization variable (TSECTA) was constructed as the sum of different classes of securitized loans: 1-4 family residential loans (RCFD B705), Home Equity Lines (RCFD B706), Credit cards receivables (RCFD B707), Auto loans (RCFD B708), Other Consumer loans (RCFD B709), Commercial and industrial loans (RCFD B710) and others assets (RCFD B711).

2- Bank liquidity was computed by adding the following items:
a) Cash and due from banks (RCFD 0010).
b) Federal funds sold and securities purshased under agreement to resell: - Until the year 2001: RCFD 1350.
- Since the year 2002: « Federal funds sold » (RCON B987) + « Securities purshased under agreement to resell » (RCFD B989).
c) Total trading assets (RCFD 3545). 